ISSN 1689-765X

\author{
Tomáš Meluzín, Marek Zinecker* \\ Brno University of Technology, Czech Republic
}

\title{
Trends in IPOs: The Evidence From Financial Markets
}

JEL Classification: $G 2, G 24$

Keywords: Corporate Finance, IPO, Trends, Financial Markets

\begin{abstract}
This paper deals with the analysis of initial public offerings of shares in terms of their quantity and the amount of capital raised by this form of financing on the world markets. Relevant global developments will be analyzed first, followed by a description of regional situation. The analysis is based on secondary data which are processed by descriptive statistics methods. The analysis of IPO trends on the world markets indicates that, in the period of 2004-2007, IPO-based financing of corporate growth gained in importance on both developed and emerging markets. The IPO segment was dominated by the largest emerging markets (Brazil, Russia, India and China) and at the same time the US American and Western European markets decline in their importance. The world-wide economic crisis of 2008 suppressed the interest in new IPOs, particularly in the developed economies. As the economy of most countries is beginning to revive, the interest in the IPO approach from businesses and investors is on the rise. It can be expected that, in the next few years, the arena of initial public offerings will be dominated by visionary companies operating on emerging markets where the execution of an IPO will constitute the key element in securing the capital essential for further expansion.
\end{abstract}

(C) Copyright Institute of Economic Research \& Polish Economic Society Branch in Torun Date of submission: February 16, 2013; date of acceptance: June 1, 2013

*Contact: meluzint@vutbr.cz; zinecker@fbm.vutbr.cz, Brno University of Technology, Faculty of Business and Management, Kolejní 2906/4, CZ-612 00 Brno, Czech Republic 


\section{Introduction}

The academic literature devotes a significant amount of research in order to better understand the IPO process. There are several theoretical explanations for the phenomenon of IPO timing.

Ibbotson and Jaffe (1975, pp. 1027-1042) focus on the prediction of 'hot' issue markets which are defined as periods in which the average first month performance of new issues is abnormally high. Their findings may help investors and issuers decide when to purchase or issue the securities. Ritter (1984, pp. 215-240), Loughran and Ritter (1995, pp. 23-51) and Ritter and Welch (2002, pp. 1795-1828) postulate that companies enter the capital market under favourable economic conditions that support their growth and development. Ritter (1984, pp. 215-240) demonstrates that initial public offerings have a cyclic nature and document the phenomenon called 'hot' issue markets. Under favourable economic conditions, IPOs experience a 'hot' market characterized by an increase in number of enterprises going public as well as proceeds. During a recession occurring 'cold' markets, exhibit low levels of IPO activity.

The current academic studies focus on the underlying economic conditions, as well as firm specific qualities (Blum 2011). Similar types of enterprises choose to go public at about the same time (Lowry, Schwert 2002, pp. 1171-1200). The waves in going public disproportionally populated with firms in particular industries and one possible reason for the 'hot' markets in IPOs is that firms, especially in certain industries, face better investment opportunities during some periods than in other times, so that IPOs merely allow for increased fund raising (Benninga et al. 2005, pp. 115-132).

Alti (2005) emphasizes that several studies have demonstrated that IPOs tend to cluster both in time and industries. However, it is less clear what causes the 'hot' and 'cold' market cycles. Empirical findings indicate a weak link between the IPO and the investment opportunities clustering. Pagano et al. (1998, pp. 27-64) and Loughran et al. (1994, pp. 165-199) find that 'hot' issue markets do not coincide with urgent funding needs and subsequent investments. Firms' decision to go public seem to be driven mainly by market timing attempts (Baker, Wurgler 2002, pp. 2219-2257).

Lowry (2002) explored extreme fluctuations in IPO volume over 37 years. He compares 'the extent to which the aggregate capital demands of private firms, the adverse-selection costs of issuing equity, and the level of investor optimism can explain these fluctuations. Results indicate that firms' demands for capital and investor sentiment determine IPO volume, in both statistical and economic terms.' 
The findings of a survey conducted by Burgstaller (2009) are consistent with these results. He examined the issuance of share capital via the Vienna Stock Exchange between 1985 and 2004. Evidence is supplied concerning the aggregate factors that explain the time-series variation in both the numbers of and proceeds from initial public offerings and seasoned equity offerings (SEOs). Results indicate that there is no cyclical sensitivity of issues, but that firms successfully time their offerings to take advantage of high stock market valuations and the associated low cost of equity capital. Corporate indebtedness and interest rates are significant determinants of SEOs in statistical and economic terms. The proceeds from IPOs, rather than funds raised by firms that are already listed, are used to finance subsequent investment.

Benninga et al. (2005, pp. 115-132) explain in the context of their model the clustering in time of IPOs and the industry concentration of IPO waves with relatively high market prices. They show that firms issue shares when the cash flows of their enterprises are relatively high, periods that coincide with high stock prices since cash flows are cross-sectionally correlated, especially within industries. The model suggests that firms are taken private when the market valuation for the expected cash flows is low (relative to the private benefits). Moreover, for the same reason that IPOs are clustered, Benninga et al. (2005, pp. 115-132) expect that reprivatization waves will be dominated by certain industries and will coincide with low share prices.

Brau and Fawcett (2006, pp. 399-436) asked 336 chief financial officers (CFOs) to compare practice to theory inter alia in the area if IPO timing. Overall stock market conditions were identified as the single most important determinant of IPO timing. Two other factors were also perceived as strongly influencing the timing of an IPO: industry conditions and the need for capital to support growth. On the contrary, two other explanations - other good firms are currently going public and first day stock performance of recent IPOs - were viewed as relatively unimportant. The data suggest that CFOs do pursue windows of opportunity, but they define these windows in terms of overall stock market and industry conditions and not by the IPO market.

In this article, the authors will assess initial public offerings of shares in terms of their quantity and the amount of capital raised by this form of financing on the world markets. Relevant global developments will be analyzed first, followed by a description of regional situation. 


\section{Survey Methodology and Data Sources}

The research approach was developed after an extensive review of IPOoriented academic literature (Brau, Fawcett 2006, pp. 399-436; Snieska, Venckuviene 2011, pp. 157-164). Research methods cover the comparative analysis of scientific literature documents and reports as well as statistic data.

The data necessary to perform the analysis were gathered from statistical yearbooks and other documents published by Paleari et al. (2008; 2009; 2010) and Ernst \& Young (2008; 2009; 2010; 2011; 2012).

The data were processed using methods of descriptive statistics.

\section{Trends in the Number of IPOs on Global Markets}

As evident from Figure 1, IPO activities correlate closely with the sequence of economic cycles. The seventeen-year period covered by the chart can be divided into several shorter intervals. After a period of economic stagnation in the early 1990's, especially in the United States and Great Britain, the years 1995-1997 were marked by a resurgence in initial public offerings of shares. The popularity of IPOs culminated in the year 2000, when 1,883 firms took advantage of them. In the US markets, these were primarily companies from the high-tech sector, which is why this time of excessive optimism is often referred to as "internet bubble". After that, during the years 2001-2003, the interest in IPOs was cooling off and their annual total does not rise above 900. Graph 1 shows that this trend reversed in 2004 and the number of completed public offerings started to climb again. The factor contributing significantly to the upswing in the IPO count and the amount of capital generated by this form of financing in the years 2004-2007 were the so-called emerging markets, i.e. markets of dynamic growth, namely those of Brazil, Russia, India and China. In 2007, there were 2014 initial public offerings processed in the world, with the total proceeds of 295 billion USD. These numbers constitute a historical record and include substantial contributions from China (259 issues for a total value of 66 billion USD), USA (172 issues valued at 34.2 billion USD), and Brazil (64 offers valued at 27.3 billion USD).

However, in 2008, due to the global economic crisis, the interest in additional IPOs cooled off on the stock markets around the world. Only 769 initial public offerings of shares were executed in that year world-wide, valued at 96 billion USD. When compared to 2007, it represents a 62\% drop in the IPO count and a $67 \%$ decline in capital value. The following year 2009 produced the smallest number of IPOs in the examined period, because only 577 
initial public offerings were issued on the global stock exchanges with a total value of 113 billion USD. The 2010 data for the number of IPOs and the amount of raised capital show an increase in both parameters, which can be interpreted as a sign of renewed corporate interest. There were 1,393 IPO issues on the world markets in 2010 with a total yield of 285 billion USD. The amount of capital generated in this manner was the second largest in the last 16 years covered by the graph. In 2011, there was a rapid decrease in the number of IPOs, as well as in the amount of gained capital. According to a Ernst \& Young Study (2012) this development was caused by investor considerations about sovereign debt issues in Europe and Standard \& Poor's downgrade of the US's credit rating.

Figure 1. Number of IPOs and the amount of globally raised capital in the period of 1995-2011

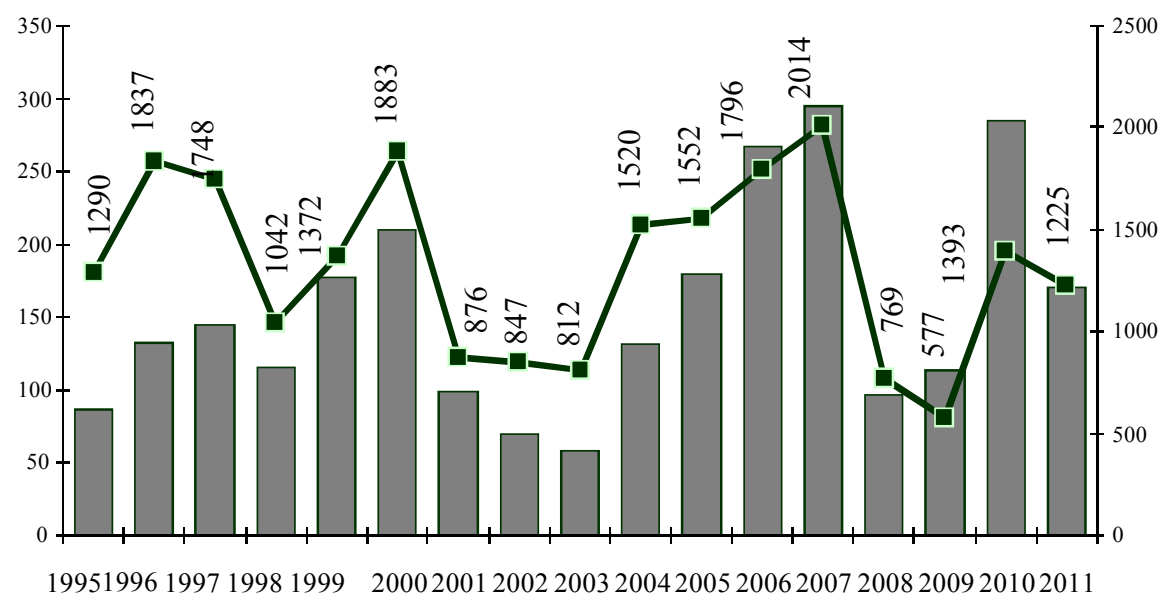

$\square$ Capital raised (US\$b) $\rightarrow$ Number of deals

Source: Ernst \& Young $(2008 ; 2009 ; 2010 ; 2011 ; 2012)$. 
Table 1 gives the basic characteristics of initial public offerings of shares issued on world stock markets in the years 2008-2011.

Table 1. Characteristics of IPOs executed in the world in the years 2008-2011

\begin{tabular}{|c|c|c|c|c|}
\hline $\begin{array}{c}\text { IPO CHARACTERIS- } \\
\text { TICS }\end{array}$ & 2008 & 2009 & 2010 & 2011 \\
\hline Number of deals & 769 & 577 & 1393 & 1225 \\
\hline $\begin{array}{l}\text { Capital raised } \\
\text { (Billion USD) }\end{array}$ & 95.8 & 112.6 & 284.6 & 169.9 \\
\hline $\begin{array}{l}\text { Average deal size } \\
\text { (Million USD) }\end{array}$ & 124.6 & 195.1 & 204.8 & 138.7 \\
\hline $\begin{array}{l}\text { PE-backed IPOs } \\
\text { (number of deals; } \\
\text { capital raised) }\end{array}$ & $\begin{array}{c}52 ; \\
10.8 \text { billion } \\
\text { USD }\end{array}$ & $\begin{array}{c}53 ; \\
16.2 \text { billion } \\
\text { USD }\end{array}$ & $\begin{array}{c}155 ; \\
35.0 \text { billion } \\
\text { USD }\end{array}$ & $\begin{array}{c}118 ; \\
38.3 \text { billion } \\
\text { USD }\end{array}$ \\
\hline $\begin{array}{l}\text { Top five sectors } \\
\text { (number of deals) }\end{array}$ & $\begin{array}{c}\text { Materials (185) } \\
\text { Industrials } \\
\quad(107) \\
\text { High-tech (84) } \\
\text { Financials (68) } \\
\text { Energy (65) }\end{array}$ & $\begin{array}{c}\text { Industrials } \\
(101) \\
\text { Materials (86) } \\
\text { High-tech (59) } \\
\text { Consumer } \\
\text { staples (49) } \\
\text { Financials (46) }\end{array}$ & $\begin{array}{c}\text { Materials (307) } \\
\text { Industrials } \\
(236) \\
\text { High-tech (180) } \\
\text { Consumer } \\
\text { staples(113) } \\
\text { Energy (94) }\end{array}$ & $\begin{array}{c}\text { Materials (268) } \\
\text { Industrials } \\
(199) \\
\text { High-tech (149) } \\
\text { Consumer } \\
\text { products }(124) \\
\text { Energy }(110)\end{array}$ \\
\hline $\begin{array}{l}\text { Top five sectors } \\
\text { (capital raised) }\end{array}$ & $\begin{array}{c}\text { Financials } \\
(\$ 25,9 b) \\
\text { Energy } \\
(\$ 18.4 b) \\
\text { Materials } \\
(\$ 16.0 b) \\
\text { Industrials } \\
(\$ 14.2 b) \\
\text { Telecoms } \\
(\$ 6.9 b)\end{array}$ & $\begin{array}{c}\text { Industrials } \\
(\$ 23.2 \mathrm{~b}) \\
\text { Financials } \\
(\$ 22.6 \mathrm{~b}) \\
\text { Energy } \\
(\$ 12.1 \mathrm{~b}) \\
\text { Real estate } \\
(\$ 10.8 \mathrm{~b}) \\
\text { Materials } \\
(\$ 7.2 \mathrm{~b})\end{array}$ & $\begin{array}{c}\text { Financials } \\
(\$ 80.0 \mathrm{~b}) \\
\text { Industrials } \\
(\$ 57.6 \mathrm{~b}) \\
\text { Materials } \\
(\$ 38.5 \mathrm{~b}) \\
\text { Energy } \\
(\$ 23.2 \mathrm{~b}) \\
\text { High-tech } \\
(\$ 20.7 \mathrm{~b})\end{array}$ & $\begin{array}{c}\text { Materials } \\
(\$ 29.2 b) \\
\text { Industrials } \\
(\$ 26.4 b) \\
\text { Energy } \\
(\$ 21.3 b) \\
\text { Financials } \\
(\$ 15.9 b) \\
\text { High-tech } \\
(\$ 14.7 b)\end{array}$ \\
\hline
\end{tabular}

Source: Ernst \& Young $(2011 ; 2012)$.

Figure 2 shows, by geographical location, the number of IPOs and the amount of capital raised in the years 2010-2011. In the last five years, the Asia-Pacific region had the lion's share of the issues and their capital value, largely because of the expanding Chinese economy. In the years 2010-2011, almost $62 \%$ of all IPOs in the world originated in that region. The EMEA region, comprised of Europe, the Middle East and Africa, is also in a strong position with respect to IPOs. It issued 584 initial public offerings during $2010-2011$, or $22 \%$ of all IPOs in the world. A significant contribution to the 
total quantity of IPOs in that region came from the Polish capital market, which absorbed 137 IPOs in the year 2011 alone. North America had 364 IPOs in 2010-2011, or less than 14\% of the global total, but the proceeds in this region were relatively high, amounting to 82 billion USD. The contribution of Central and South America was small, particularly in the years 20102011, when only 57 IPOs were released. These were apparently larger issues though, because the capital raised in that region reached 18 billion USD.

Figure 2. Number of IPOs and the value of raised capital in the years 2010-2011 by geographical location

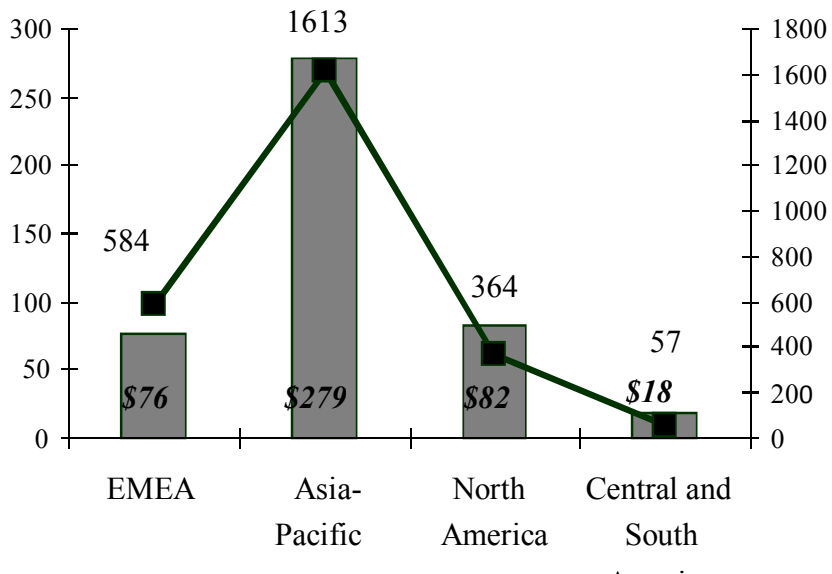

America

Capital raised (US\$b)

- Number of deals

Source: Author's interpretation of Ernst \& Young data (2012).

\section{American Markets}

The market for initial public offerings of stock in the USA underwent a period of recession in wake of the adoption of regulatory measures for corporate governance, which manifested itself by diminished corporate interest in IPOs. One of the most important legal standards enacted to improve the supervisory function was the so-called Sarbanes Oxley Act of 2002, which instituted changes focusing especially on accounting and auditing, as well as the 
structure and activity of management councils. At the same time, Public Company Accounting Oversight Board was established to set appropriate accounting and auditing standards. These measures, adopted after it became known that some American companies had misrepresented their accounting to mislead investors, changed the corporate thinking about using IPOs in the United States to finance development. The smaller companies, for which the mandatory compliance with the Sarbanes Oxley Act is a costly proposition, started to weigh the possibility of issuing IPOs on foreign markets, preferably $\mathrm{AIM}^{1}$ in London.

The bigger administrative burden placed on issuers by the Sarbanes Oxley Act implies that the likely candidates for doing IPOs on the American market at this time are well-established companies that have no problem complying with even the strictest dictates of corporate governance. The situation is therefore a little different than it was a few years ago. In the 1990 's, the average age of an IPO-issuing company on the US market was 57 years, whereas currently it stands at about 8 years. The annual IPO count and the value of capital raised by this form of financing in the United States in the period of 2002-2011 are displayed in Figure 3.

Even though the adoption of the Sarbanes Oxley Act had a negative impact on the annual frequency and the raised capital value of IPOs, it was only a temporary setback, which factored prominently only in the years 20022003. The acceleration of economic growth overshadowed that phenomenon and, from 2004, reignited the interest in initial public offerings. Due to the global economic recession, preceded by problems in the US mortgage market, the interest in additional IPOs receded in 2008. Only 37 IPOs were issued in the United States that year, which, relative to 2007, represents a drop of $78 \%$. The decline in the raised capital value (21\%) was not as dramatic, but only thanks to an issue from Visa Inc. valued at more than 19 billion USD $^{3}$. In 2009, the number of IPOs in the United States increased to 67 and the upward trend continued in the following year, as evident in Graph 3. There were 163 IPOs issued in 2010, with the total value of 44 billion USD. The capital value generated by IPO activities in 2010 is the highest in the last nine years. In 2011 there was a moderate decline in the number of IPOs as well in the amount of gained capital.

${ }^{1}$ AIM is an abbreviation of Alternative Investment Market at London Stock Exchange. This market was established in 1995 with the objective of letting even smaller companies enter the stock market. In comparison with the main martket of London Stock Exchange, it is less regulated. 
Figure 3. Number of IPOs and the value of raised capital in the US in the period of 2002-2011

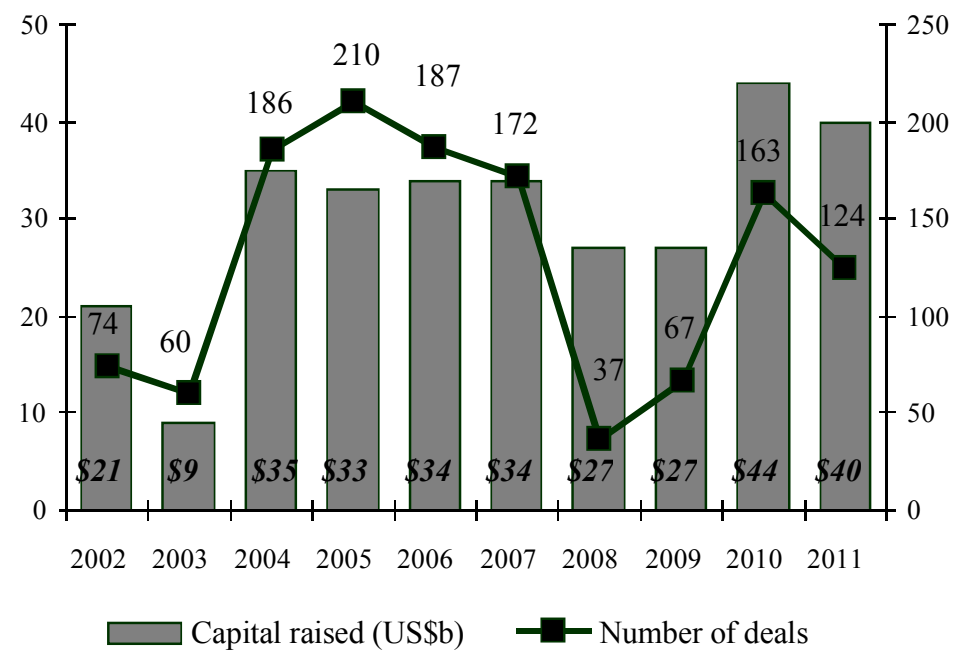

Source: Ernst \& Young (2008; 2009; 2010; 2011; 2012).

Table 2 gives the basic characteristics of initial public offerings conducted in the US in the years 2008-2011.

Table 2. Basic characteristics of IPOs in the US in the years 2008-2011

\begin{tabular}{|l|c|c|c|c|}
\hline $\begin{array}{l}\text { IPO CHARACTERIS- } \\
\text { TICS }\end{array}$ & $\mathbf{2 0 0 8}$ & $\mathbf{2 0 0 9}$ & $\mathbf{2 0 1 0}$ & $\mathbf{2 0 1 1}$ \\
\hline \hline Number of deals & 37 & 67 & 163 & 124 \\
\hline Capital raised (US\$b) & 26.8 & 27.3 & 43.5 & 40.2 \\
\hline $\begin{array}{l}\text { Average deal size } \\
\text { (US\$m) }\end{array}$ & $724.9^{2}$ & 406.9 & 145.7 & 324.3 \\
\hline $\begin{array}{l}\text { PE-backed IPOs } \\
\text { (number of deals; } \\
\text { capital raised) }\end{array}$ & $\begin{array}{c}8 \\
\text { Nas\$b }\end{array}$ & $\begin{array}{c}28 \\
9.0 \mathrm{US} \$ \mathrm{~b}\end{array}$ & $\begin{array}{c}33 \\
6.1 \mathrm{US} \$ \mathrm{~b}\end{array}$ & $\begin{array}{c}56 \\
26.7 \mathrm{US} \$ \mathrm{~b}\end{array}$ \\
\hline
\end{tabular}

${ }^{2}$ This was the largest IPO in the history of the United States. If excluded, the average issue volume would have been 199.2 million USD. 
Table 2 continued

\begin{tabular}{|c|c|c|c|c|}
\hline $\begin{array}{l}\text { IPO CHARACTERIS- } \\
\text { TICS }\end{array}$ & 2008 & 2009 & 2010 & 2011 \\
\hline $\begin{array}{l}\text { Top five sectors } \\
\text { (number of deals) }\end{array}$ & $\begin{array}{c}\text { Energy (8) } \\
\text { Financials (5) } \\
\text { Health care (5) } \\
\text { Industrials (5) } \\
\text { High-tech (4) }\end{array}$ & $\begin{array}{l}\text { High-tech (12) } \\
\text { Health care (9) } \\
\text { Real estate (9) } \\
\text { Industrials (8) } \\
\text { Financials (5) }\end{array}$ & $\begin{array}{c}\text { High-tech (35) } \\
\text { Health care } \\
\quad(21) \\
\text { Financials (20) } \\
\text { Industrials (17) } \\
\text { Energy (14) }\end{array}$ & $\begin{array}{c}\text { High-tech (33) } \\
\text { Energy (25) } \\
\text { Health care } \\
(16) \\
\text { Consumer } \\
\text { products }(9) \\
\text { Real estate (9) }\end{array}$ \\
\hline $\begin{array}{l}\text { Top five sectors } \\
\text { (capital raised) }\end{array}$ & $\begin{array}{c}\text { Financials } \\
(\$ 20.0 \mathrm{~b}) \\
\text { Energy }(\$ 2.7 \mathrm{~b}) \\
\text { Materials } \\
(\$ 1.3 \mathrm{~b}) \\
\text { Industrials } \\
(\$ 0.8 \mathrm{~b}) \\
\text { High- } \\
\text { tech }(\$ 0.6 \mathrm{~b})\end{array}$ & $\begin{array}{c}\text { Financials } \\
(\$ 10.5 \mathrm{~b}) \\
\text { High-tech } \\
(\$ 3.2 \mathrm{~b}) \\
\text { Real estate } \\
(\$ 2.9 \mathrm{~b}) \\
\text { Health care } \\
(\$ 2.2 \mathrm{~b}) \\
\text { Energy }(\$ 1.4 \mathrm{~b})\end{array}$ & $\begin{array}{c}\text { Industrials } \\
(\$ 22.0 \mathrm{~b}) \\
\text { High-tech } \\
(\$ 4.9 \mathrm{~b}) \\
\text { Financials } \\
(\$ 4.1 \mathrm{~b}) \\
\text { Energy }(\$ 3.5 \mathrm{~b}) \\
\text { Real estate } \\
(\$ 2.0 \mathrm{~b})\end{array}$ & $\begin{array}{c}\text { Energy }(\$ 9.3 \mathrm{~b}) \\
\text { High-tech } \\
(\$ 8.1 \mathrm{~b}) \\
\text { Health care } \\
(\$ 5.9 \mathrm{~b}) \\
\text { Consumer } \\
\text { products } \\
(\$ 3.9 \mathrm{~b}) \\
\text { Retail }(\$ 3.8 \mathrm{~b})\end{array}$ \\
\hline
\end{tabular}

Source: Ernst \& Young $(2011 ; 2012)$.

\section{European Markets}

The European markets are in a strong position in terms of IPO numbers and even more so in terms of generated capital value. Unlike the United States, where the imposition of the Sarbanes Oxley Act had a dampening effect on the number of initial public offerings, the regulatory standards ${ }^{3}$ adopted in Europe did not have an appreciable impact on the IPO market.

Figure 4 tracks the annual frequency and the capital value on the European markets in the period of 2002-2011. The graph shows a significant increase in the IPO activity on these markets in the years 2004-2007. In 2008, many of the planned IPOs were deferred due to the economic downturn, causing a precipitous drop in both the quantity and the capital value of IPOs issued that year. A significant proportion of all IPOs (201 issues) and their capital (17 billion USD) came from the companies operating in emerging markets. In 2008, these markets floated 7 out of 10 largest European IPOs (of which one was in the Czech Republic, two in Poland, and two in Russia). In 2009, the European markets experienced further decline in the number of IPOs along with their capital value. However, the results for 2010 and 2011 show that the European markets, like markets on other continents, have seen

\footnotetext{
${ }^{3}$ This refers mainly to the implementation of International Financial Reporting Standards (IFRS) and a European Community directive on securities prospectus from 2003.
} 
an increase in IPO activities, which may signify that the interest in this form of corporate financing is coming back. In 2011, there were 266 IPOs with the total value of 29.7 billion USD released in Europe, and the stock exchanges in London and Warsaw are now considered to be the most productive markets.

Figure 4. Number of IPOs and the value of capital raised on the European markets in the period of 2002-2011

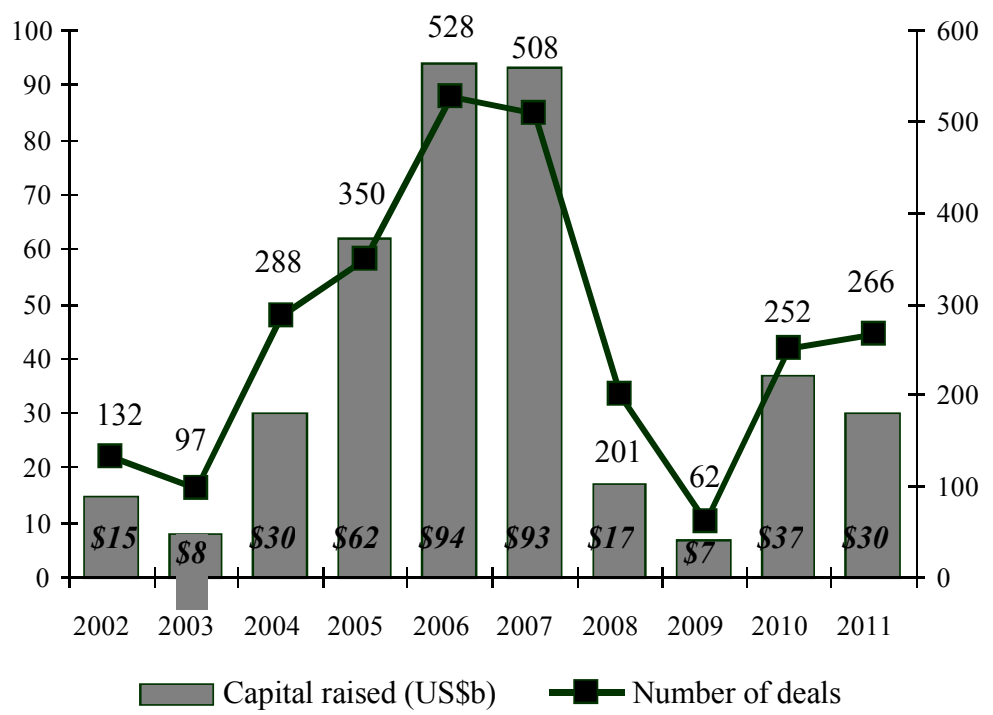

Source: Ernst \& Young (2008; 2009; 2010; 2011; 2012).

Table 3 summarizes the basic characteristics of initial public offerings that appeared on the European markets in the years 2008-2011. 
Table 3. Basic characteristics of IPOs in the US in the years 2008-2011

\begin{tabular}{|c|c|c|c|c|}
\hline IPO CHARACTERISTICS & 2008 & 2009 & 2010 & 2011 \\
\hline Number of deals & 201 & 62 & 252 & 266 \\
\hline $\begin{array}{l}\text { Capital raised } \\
\text { (US\$b) }\end{array}$ & 16.8 & 7.4 & 36.7 & 29.7 \\
\hline $\begin{array}{l}\text { Average deal size } \\
\text { (US\$m) }\end{array}$ & 83.4 & 119.4 & 147.2 & 111.6 \\
\hline $\begin{array}{l}\text { PE-backed IPOs (num- } \\
\text { ber of deals; capital } \\
\text { raised) }\end{array}$ & $\begin{array}{c}3 \\
3.4 \mathrm{US} \$ b\end{array}$ & $\begin{array}{c}3 \\
0.8 \mathrm{US} \$ \mathrm{~b}\end{array}$ & $\begin{array}{c}18 \\
9.5 \mathrm{US} \$ \mathrm{~b}\end{array}$ & $\begin{array}{c}11 \\
2.8 \mathrm{US} \$ \mathrm{~b}\end{array}$ \\
\hline $\begin{array}{l}\text { Top five sectors } \\
\text { (number of deals) }\end{array}$ & $\begin{array}{l}\text { High-tech (28) } \\
\text { Materials (27) } \\
\text { Industrials (25) } \\
\text { Consumer } \\
\text { products (23) } \\
\text { Energy (18) }\end{array}$ & $\begin{array}{c}\text { Industrials } \\
\text { (16) } \\
\text { Materials (7) } \\
\text { Financials (7) } \\
\text { Real estate (6) } \\
\text { Health care (5) }\end{array}$ & $\begin{array}{c}\text { Materials (31) } \\
\text { High-tech (29) } \\
\text { Consumer } \\
\text { products (28) } \\
\text { Industrials } \\
(28) \\
\text { Consumer } \\
\text { staples (26) } \\
\end{array}$ & $\begin{array}{c}\text { Consumer } \\
\text { products (44) } \\
\text { Industrials } \\
(41) \\
\text { Materials (30) } \\
\text { High-tech (26) } \\
\text { Energy (25) }\end{array}$ \\
\hline $\begin{array}{l}\text { Top five sectors } \\
\text { (capital raised) }\end{array}$ & \begin{tabular}{|c|} 
Energy $(\$ 5.3 b)$ \\
Materials \\
$(\$ 4.7 b)$ \\
Telecoms \\
$(\$ 2.5 b)$ \\
Industrials \\
$(\$ 0.9 \mathrm{~b})$ \\
Financials \\
$(\$ 0.9 \mathrm{~b})$ \\
\end{tabular} & $\begin{array}{c}\text { Energy }(\$ 2.3 \mathrm{~b}) \\
\text { Financials } \\
(\$ 2.2 \mathrm{~b}) \\
\text { Industrials } \\
(\$ 1.6 \mathrm{~b}) \\
\text { Real estate } \\
(\$ 0.6 \mathrm{~b}) \\
\text { Materials } \\
(\$ 0.2 \mathrm{~b})\end{array}$ & $\begin{array}{c}\text { Energy }(\$ 8.3 b) \\
\text { Materials } \\
(\$ 6.4 b) \\
\text { Financials } \\
(\$ 5.9 b) \\
\text { High-tech } \\
(\$ 3.8 b) \\
\text { Retail }(\$ 3.5 b)\end{array}$ & $\begin{array}{c}\text { Materials } \\
(\$ 13.3 b) \\
\text { Financials } \\
(\$ 6.4 b) \\
\text { Energy }(\$ 2.8 b) \\
\text { Industrials } \\
(\$ 2.7 b) \\
\text { Consumer } \\
\text { staples }(\$ 1.3 b)\end{array}$ \\
\hline
\end{tabular}

Source: Ernst \& Young $(2011 ; 2012)$.

\section{Markets of Central and Eastern Europe}

Table 4 documents the frequency of initial public offerings released on the main markets of selected stock exchanges in the countries of Central and Eastern Europe. It demonstrates that it is not very common in these countries to rely on capital markets for corporate financing. The exception is Poland, whose capital market is widely considered to be the most developed among the Central and Eastern European countries. This is evident from the large number of IPOs issued on the Polish capital market in recent years. As mentioned before, Warsaw Stock Exchange now belongs to the European stock exchanges with the highest number of completed IPOs. 
Table 4. Number of IPOs on Central and Eastern European Markets in the years 2002-2009

\begin{tabular}{|l|r|r|r|r|r|r|r|r|}
\hline STOCK ExCHANGE & $\mathbf{2 0 0 2}$ & $\mathbf{2 0 0 3}$ & $\mathbf{2 0 0 4}$ & $\mathbf{2 0 0 5}$ & $\mathbf{2 0 0 6}$ & $\mathbf{2 0 0 7}$ & $\mathbf{2 0 0 8}$ & $\mathbf{2 0 0 9}$ \\
\hline Warsaw Stock Exchange & 5 & 6 & 36 & 34 & 35 & 68 & 29 & 10 \\
Prague Stock Exchange & 0 & 0 & 1 & 0 & 2 & 1 & 1 & 0 \\
Budapest Stock Exchange & 0 & 0 & 1 & 0 & 3 & 0 & 1 & 2 \\
Bratislava Stock Exchange & 1 & 0 & 0 & 0 & 0 & 0 & 0 & 0 \\
Ljubljana Stock Exchange & 0 & 0 & 0 & 0 & 2 & 1 & 1 & 0 \\
\hline Total & $\mathbf{6}$ & $\mathbf{6}$ & $\mathbf{3 8}$ & $\mathbf{3 4}$ & $\mathbf{4 2}$ & $\mathbf{7 0}$ & $\mathbf{3 1}$ & $\mathbf{1 2}$ \\
\hline
\end{tabular}

Source: Paleari et al. $(2008 ; 2009 ; 2010)$.

\section{Markets in the Middle East and Africa}

Within the region of the Middle East and Africa, the most active capital markets for IPOs are to be found in Saudi Arabia and United Arab Emirates. The interest in initial public offerings of shares in the Middle East is sustained mainly by high market liquidity, privatization, and enduring economic prosperity. The progression of annual IPO counts and the total proceeds in the Middle East and Africa in the period of 2004-2011 are presented in the Figure 5.

Figure 5 demonstrates that this region has been relatively immune to the global economic recession of 2008, since it implemented 77 initial public offerings with the total value of 15.3 billion USD in that year. The drop in the number of IPOs and the value of the raised capital in this region came a year later, in 2009, when only 22 IPOs were absorbed with a total value of 2.4 billion USD. In the years 2010-2011, there was a slight growth on the IPO market in this region. 
Figure 5. Number of IPOs and the value of capital raised in the region of the Middle East and Africa in the period of 2004-2011

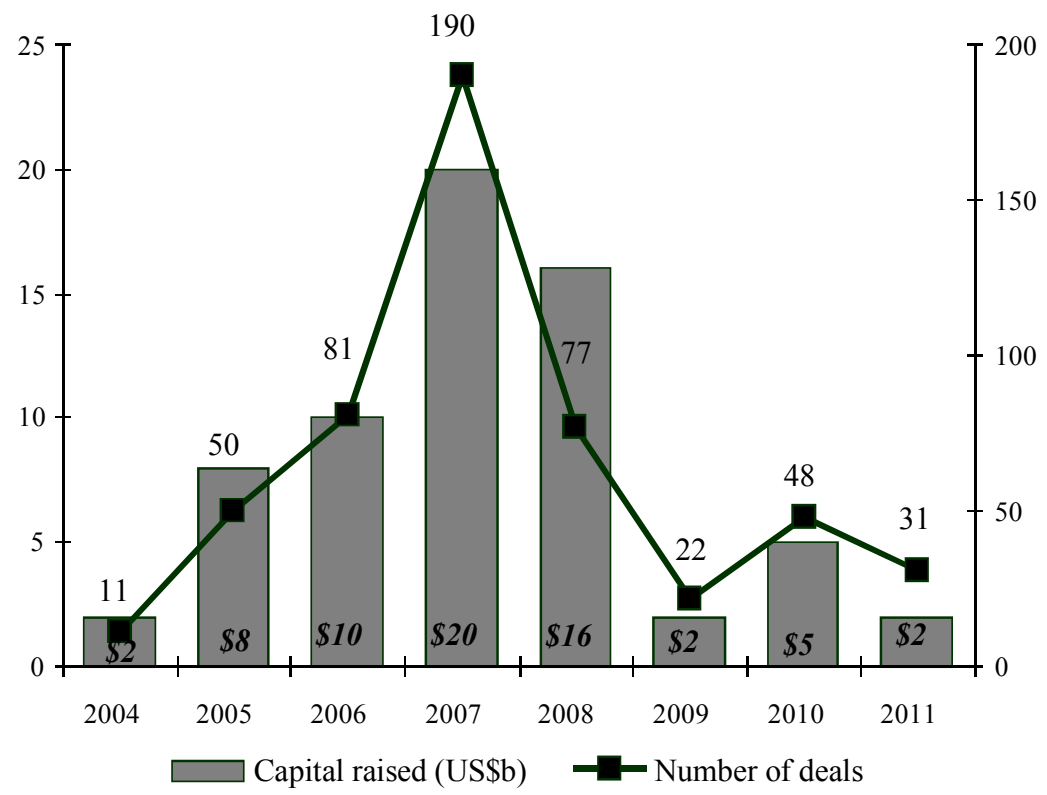

Source: Ernst \& Young (2008; 2009; 2010; 2011; 2012).

Table 5 contains the basic characteristics of initial public offerings of shares issued in the Middle East and Africa in the years 2008-2011.

Table 5. Basic characteristics of IPOs issued in the Middle East and Africa in the years 2008-2011

\begin{tabular}{|l|c|c|c|c|}
\hline $\begin{array}{l}\text { IPO CHARACTERIS- } \\
\text { TICS }\end{array}$ & $\mathbf{2 0 0 8}$ & $\mathbf{2 0 0 9}$ & $\mathbf{2 0 1 0}$ & $\mathbf{2 0 1 1}$ \\
\hline \hline Number of deals & 77 & 22 & 26 & 31 \\
\hline Capital raised (US\$b) & 15.8 & 2.4 & 5.0 & 1.8 \\
\hline $\begin{array}{l}\text { Average deal size } \\
(\text { US\$m) }\end{array}$ & 205.5 & 109.6 & 103.3 & 58.6 \\
\hline
\end{tabular}


Table 5 continued

\begin{tabular}{|l|c|c|c|c|}
\hline $\begin{array}{l}\text { IPO CHARACTERIS- } \\
\text { TICS }\end{array}$ & $\mathbf{2 0 0 8}$ & $\mathbf{2 0 0 9}$ & $\mathbf{2 0 1 0}$ & $\mathbf{2 0 1 1}$ \\
\hline \hline $\begin{array}{l}\text { Top 2 sectors (num- } \\
\text { ber of deals) }\end{array}$ & $\begin{array}{c}\text { Financials (26) } \\
\text { Industrials (12) }\end{array}$ & $\begin{array}{c}\text { Financials (12) } \\
\text { Telecoms (4) }\end{array}$ & $\begin{array}{c}\text { Financials (9) } \\
\text { Industrials (8) }\end{array}$ & $\begin{array}{c}\text { Consumer } \\
\text { products (7) } \\
\text { Financials (6) }\end{array}$ \\
\hline $\begin{array}{l}\text { Top 2 sectors (capital } \\
\text { raised) }\end{array}$ & $\begin{array}{c}\text { Telecoms } \\
(\$ 4.3 \mathrm{~b})\end{array}$ & $\begin{array}{c}\text { Telecoms } \\
(\$ 1.1 \mathrm{~b}) \\
\text { Materials }\end{array}$ & $\begin{array}{c}\text { Materials } \\
(\$ 1.2 \mathrm{~b}) \\
\text { Real estate } \\
(\$ 1.0 \mathrm{~b})\end{array}$ & $\begin{array}{c}\text { Real estate } \\
(\$ 0.8 \mathrm{~b}) \\
\text { Consumer } \\
\text { products } \\
(\$ 0.6 \mathrm{~b})\end{array}$ \\
\hline
\end{tabular}

Source: Ernst \& Young $(2011 ; 2012)$.

\section{Asian Markets}

Asia is the region with the highest IPO count and the largest value of capital raised by this form of financing in the world. This is primarily because of the economic expansion in China. From 2006 onward, that country has had the highest number of IPOs in the world. As shown in Figure 6, China implemented 440 initial public offerings of shares in 2010 with a total yield of 130 billion USD. In comparison with the previous year, this represents a $177 \%$ jump in the IPO count and a $152 \%$ boost in capital value. Much of it can be attributed to the interest in IPOs on the part of small and mid-sized businesses in the sectors of consumer goods, infrastructure, clean technology and pharmaceuticals, as well as some large, government-owned enterprises. In 2011, China remains the global IPO powerhouse. The Hong Kong, Shenzhen and Shanghai stock exchanges were once again among the top five global markets, ranked by the capital raised. Despite a very tough year, IPO activity on Greater China exchanges accounted for $40 \%$ of global IPO funds raised in 2011. 
Figure 6. Number of IPOs and the value of capital raised in China in the years 20042011

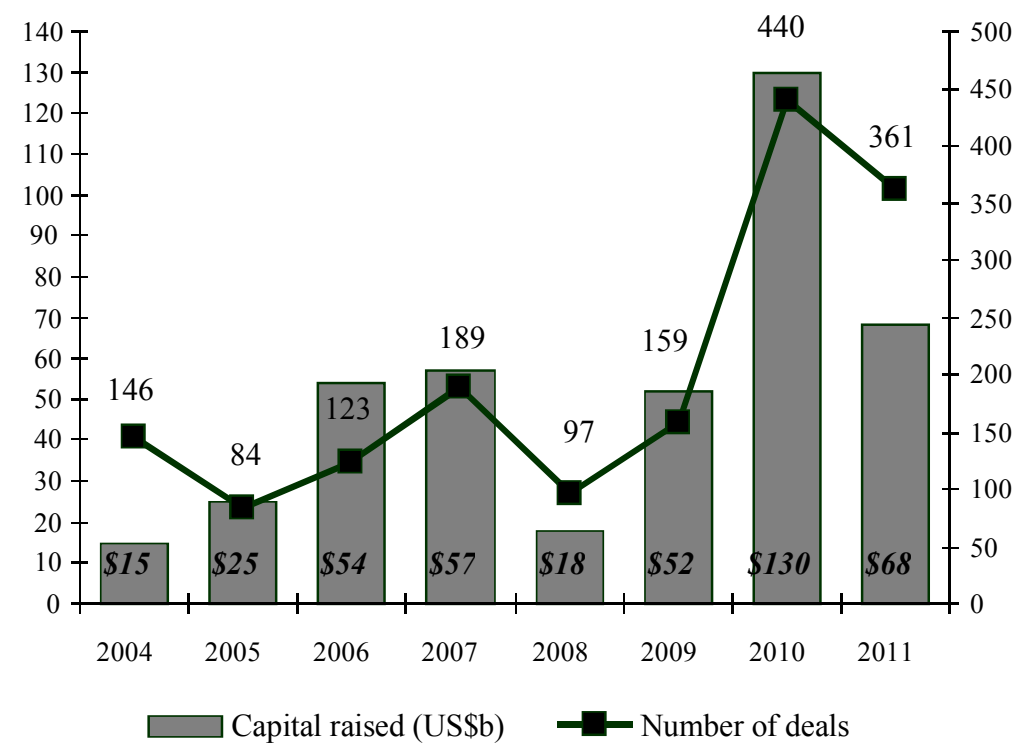

Source: Ernst \& Young $(2011 ; 2012)$.

Table 6 lists the basic characteristics of initial public offers of shares in China in the years 2008-2011.

Table 6. Basic characteristics of IPOs issued in China in the years 2008-2011

\begin{tabular}{|c|c|c|c|c|}
\hline IPO CHARACTERISTICS & $\mathbf{2 0 0 8}$ & $\mathbf{2 0 0 9}$ & $\mathbf{2 0 1 0}$ & $\mathbf{2 0 1 1}$ \\
\hline \hline Number of deals & 97 & 159 & 440 & 361 \\
\hline \begin{tabular}{c} 
Capital raised (US\$b) \\
\hline $\begin{array}{c}\text { Average deal size } \\
\text { (US\$m) }\end{array}$
\end{tabular} & 17.5 & 51.5 & 129.8 & 68.4 \\
\hline
\end{tabular}


Table 6 continued

\begin{tabular}{|c|c|c|c|c|}
\hline IPO CHARACTERISTICS & 2008 & 2009 & 2010 & 2011 \\
\hline $\begin{array}{l}\text { Top five sectors (num- } \\
\text { ber of deals) }\end{array}$ & $\begin{array}{l}\text { Materials (26) } \\
\text { Industrials } \\
(24) \\
\text { Consumer } \\
\text { staples (8) } \\
\text { Retail (8) } \\
\text { High-tech (7) }\end{array}$ & $\begin{array}{c}\text { Industrials (34) } \\
\text { Materials (22) } \\
\text { Consumer staples } \\
(19) \\
\text { High-tech (18) } \\
\text { Consumer products } \\
\quad(15)\end{array}$ & $\begin{array}{c}\text { Industrials } \\
(103) \\
\text { Materials (97) } \\
\text { High-tech } \\
(70) \\
\text { Consumer } \\
\text { staples (44) } \\
\text { Health care } \\
(28)\end{array}$ & \begin{tabular}{|c} 
Industrials \\
$(84)$ \\
Materials (72) \\
High-tech \\
$(40)$ \\
Consumer \\
staples (36) \\
Consumer \\
products (28)
\end{tabular} \\
\hline $\begin{array}{l}\text { Top five sectors (capi- } \\
\text { tal raised) }\end{array}$ & $\begin{array}{c}\text { Industrials } \\
(\$ 8.8 \mathrm{~b}) \\
\text { Materials } \\
(\$ 3.0 \mathrm{~b}) \\
\text { Consumer } \\
\text { staples } \\
(\$ 1.8 \mathrm{~b}) \\
\text { Retail }(\$ 1.0 \mathrm{~b}) \\
\text { Energy } \\
(\$ 0.8 \mathrm{~b}) \\
\end{array}$ & $\begin{array}{c}\text { Industrials }(\$ 19.7 \mathrm{~b}) \\
\text { Materials }(\$ 5.4 \mathrm{~b}) \\
\text { Real estate }(\$ 5.2 \mathrm{~b}) \\
\text { Media\&entertain. } \\
(\$ 4.8 \mathrm{~b}) \\
\text { Energy }(\$ 3.5 \mathrm{~b})\end{array}$ & $\begin{array}{c}\text { Financials } \\
\text { (\$51.1b) } \\
\text { Industrials } \\
(\$ 20.1 \mathrm{~b}) \\
\text { Materials } \\
(\$ 18.5 \mathrm{~b}) \\
\text { High-tech } \\
\text { (\$10.6b) } \\
\text { Health care } \\
(\$ 6.1 \mathrm{~b})\end{array}$ & $\begin{array}{c}\text { Materials } \\
\text { (\$11.9b) } \\
\text { Industrials } \\
(\$ 11.7 \mathrm{~b}) \\
\text { Energy } \\
(\$ 6.8 \mathrm{~b}) \\
\text { Retail }(\$ 6.6 \mathrm{~b}) \\
\text { Financials } \\
(\$ 6.2 \mathrm{~b})\end{array}$ \\
\hline
\end{tabular}

Source: Ernst \& Young $(2011 ; 2012)$.

\section{Conclusions}

The analysis of IPO trends on the world markets indicates that, in the period of 2004-2007, IPO-based financing of corporate growth gained in importance on both developed and emerging markets. A record number of IPOs on the world markets and the largest capital value within the last sixteen years materialized in the year 2007. Of that, more than $40 \%$ of all IPOs in the world appeared on the emerging markets. It is obviously a completely different situation than, say, ten years ago, when the IPO segment was dominated by the American and the European markets, and the largest emerging markets (Brazil, Russia, India and China) attracted only 5\% of the globally generated capital.

The world-wide economic crisis of 2008 suppressed the interest in new IPOs, particularly in the developed economies. In the following year, the number of IPOs in the world was the lowest in the last sixteen years as most companies postponed any action waiting for the economic situation to get better and more conducive to further development. This interaction confirms the fact that IPO activities tend to track the underlying economic cycle. In 
a growing economy, the share-generated capital becomes available because of high profit expectations harbored by issuers and investors alike.

As the economy of most countries is beginning to revive, the interest in the IPO approach from businesses and investors is on the rise. It can be expected that, in the next few years, the arena of initial public offerings will be dominated by visionary companies operating on emerging markets, for whom the execution of an IPO will constitute the key element in securing the capital essential for further expansion. The investors will then get the opportunity to participate in future growth and profit greatly from the rise in share value.

\section{References}

Alti A. (2005), IPO Market Timing. Austin: University of Texas, http://www2.mccombs.utexas.edu/faculty/aydogan.alti/Research/ipo.pdf (201315-03).

Baker M., Wurgler, J. (2000), The equity share in new issues and aggregate stock returns, ,Journal of Finance”, Vol. 55.

Blum R. (2011), IPO Timing Determinants. Durham, North Carolina: Duke University, Honors thesis submitted in partial fulfillment of the requirements for Graduation with Distinction in Economics in Trinity College of Duke University.

Benninga S., Helmantel M., Sarig O. (2005), The timing of initial public offerings, „Journal of Financial Economics”, Vol. 75.

Brau J.C., Fawcett S.E. (2006), Initial Public Offerings: An Analysis of Theory and Practise. "Journal of Finance", Vol. 61, No 1.

Burgstaller J. (2003), When and why do Austrian companies issue shares?. Linz: Johannes Kepler University. Working Paper No. 0503, http://www.economics. uni-linz.ac.at/papers/2005/wp0503.pdf, (2013-15-03).

Ernst \& Young (2012), Global IPO Trends 2012, http://www.ey.com/GL/en/ Services/Strategic-Growth-Markets/Global-IPO-trends-2012--Eight-IPO-trends-towatch-in-2012 (2012-12-12).

Ernst \& Young (2011), Global IPO Trends 2011, http://www.ey.com/Publica tion/vwLUAssets/Global-IPO-trends 2011/\$FILE/Global\%20IPO\%20trends\%2 02011.pdf (2011-09-11).

Ernst \& Young (2010), Global IPO Trends 2010, http://www.ey.com/Pub lication/vwLUAssets/EY_Global_IPO_Trends_2010/\$FILE/E Global_IPO_Tre nds 2010.pdf (2010-08-10).

Ernst \& Young (2009), Shifting landscape - Are you ready? Global IPO Trends Report 2009, http://www.ey.com/GL/en/Newsroom/News-releases/Media--Press-Release---Ernst---Young-launches-Global-IPO-trends-report-2009 ( 200906-05).

Ernst \& Young (2008), Growth during economic uncertainty: Global IPO Trends Report 2008, http://www.ey.com/global/content.nsf/International/SGM IPO_Trends_2008 (2008-06-02). 
Ernst \& Young (2007), Globalization: Global IPO Trends Report 2007, http://www.ey.com/Global/Assets.nsf/Russia_E/Global_IPO_Trends_Report_Fin al_Report_v2/\$file/Global_IPO_Trends_Report_Final_Report_v2.pdf (2007-0918).

Ibbotson R.G., Jaffe J.J. (1975), 'Hot issue’ markets, “Journal of Finance”, Vol. 30, No. 4.

Loughran T., Ritter J.R. (1995), The New Issues Puzzle, “Journal of Finance”, Vol. 50, No. 1, 23-51.

Loughran T., Ritter J.R., Rydqvist K. (1994), Initial Public Offerings: International Insight, "Pacific-Basin Finance Journal", Vol. 2.

Lowry M., Schwert G. . (2002), IPO Market Cycles: Bubbles or Sequential Learning? „Journal of Finance”, Vol. 67, No. 3.

Pagano, M., \& Panetta, F., \& Zingales, L. (1998), Why do companies go public: An empirical analysis, "Journal of Finance", Vol. 53.

Paleari S. et al. (2008), Academic EurIPO Fact Book 2008, Bergamo: Universoft.

Paleari S. et al. (2009). Academic EurIPO Fact Book 2009, Bergamo: Universoft.

Paleari S. et al. (2010). Academic EurIPO Fact Book 2010, Bergamo: Universoft.

Ritter J.R. (1984), The 'Hot Issue' Market of 1980, „Journal of Business” Vol. 57, No. 2, 215-240.

Ritter J.R., Welch I. (2002), A review of IPO activity, pricing, and allocations, "Journal of Finance", Vol. 57, No. 4.

Snieska V., Venckuviene V. (2011), Hybrid Venture Capital Funds in Lithuania: Motives, Factors and Present State of Development, "Inzinerine EkonomikaEngineering Economics", Vol. 22, No. 2. 